\title{
Bacterial Concrete- A Sustainable Solution for Concrete Maintenance
}

\author{
Shubham Ajay Puranik, Siddharth Jain, G. Sritam, Sayali Sandbhor
}

\begin{abstract}
Cracks formed in concrete are inescapable and are one of the major reasons for the weaknesses of concrete. Majorly water along with other components penetrate through these cracks resulting in corrosion thereby reducing the strength of concrete directly hampering its life. The objective of present research work is to promote sustainable development and to identify sustainable materials for treating cracks formed in concrete. Various researches have shown positive results by adding calcite precipitating bacteria in concrete, also known as bacterial concrete or self-healing concrete. This research is dedicated to check the suitability of mixing these self-healing calcite depositing bacteria with concrete in order to increase the compressive strength of concrete, reduce its permeability and seepage of water by bio-mineralization process. Substantial increase in strength is observed in concrete specimens when casted with bacterial solution. The study has devised methods or ways to test the effect of use of bacteria in concrete. Tests on concrete slab with various combinations of bacterial solution as well as varied percentage of bacterial solution have been conducted. Use of bacterial solution for surface application on slab to test the sealing capacity is done. Results have been compared with conventional concrete. Biological modifications of construction materials are the need of the hour for strength improvement and long term sustainability. The present study proposes a promising sustainable repair method for concrete.
\end{abstract}

Index Terms: Bacterial concrete, cracks, durability, repair, self-healing.

\section{INTRODUCTION}

Concrete is one of the massively used construction and building materials, and has a great susceptibility of forming cracks. These cracks develop due to several factors like rate and quantity of drying, drying shrinkage, tensile strength and strain, elasticity, creep etc. Formation of these cracks results in significant reduction in concrete service life and high renewal costs. The formation of cracks and their succession under the effect of tensile stresses is a major disadvantage of concrete making it exposed to toxic environment due to entry of detrimental compounds. Manufactured materials like epoxies are used for crack remedy. Yet, they pose their own drawbacks. They are not only expensive but also alter the appearance of the structure to a certain extent and need consistent upkeep. Consequently, bacteria induced calcium carbonate (calcite)

Revised Manuscript Received on September 10, 2019.

Shubham Puranik, Graduate Scholar, Civil Engineering Department, SIT, Symbiosis International (Deemed University), Pune, Maharashtra, India.

Siddharth Jain, Post Graduate Scholar, Construction management, MIT, WPU, Pune, Maharashtra, India.

Sritam G., Post Graduate Scholar, MBA- Finance, ITM, Mumbai Maharashtra, India.

Dr. Sayali Sandbhor, Assistant Professor, Civil Engineering Department, SIT, Symbiosis International (Deemed University), Pune, Maharashtra, India. precipitation is recommended as an alternative. When the concrete hardens, cracks are healed by bacterial reaction as water ingresses through the cracks. As bacteria in concrete carry out process of self-healing of cracks, this concrete is also known as Self-Healing Concrete.

Concrete remediation by the addition of bacteria is an unconventional concept in ongoing research in concrete and its properties. It is a novice technique with an old perspective that microbial mineral sedimentation persistently takes place naturally in the environment. The futuristic aim of the study is interpreting the impact and importance of micro-organisms in concrete. Therefore, bacterially induced calcium carbonate precipitation has been recommended as a substitute and eco-friendly crack mending process. The countermeasure will save manual inspections, repairs and also would increase the durability of the structure. Addition of bacteria as an agent for crack repair in the concrete mixture would not only prove economical but also save the environment from the harmful effects of using other chemical processes of crack treatment. Using bacteria as binder and fillers in concrete would also improve the performance of concrete in terms of its strength and durability.

\section{A. Crack Healing Mechanism}

Bacterial concrete is an outcome of the reaction of a calcium based nutrient and non-reacted limestone. The cracks appeared on the building are healed with the help of bacteria. Special form of bacteria belonging to 'Bacillus' family, is used along with calcium lactate as a nutrient. These bacteria can be in dormant stage for approximately 200 years and after its contact with water, deposit calcite precipitate in cracks that follows process as shown in Fig 1 below.

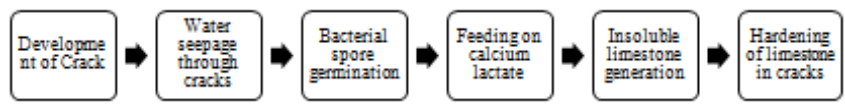

Figure 1: Process of crack healing

Once the cracks appear in the concrete, water begins to percolate in concrete through these openings. The bacterial spores germinate and start feeding on calcium as water trickles into the cracks. Conversion of soluble calcium lactate into insoluble limestone takes place as the oxygen is consumed in the chemical reactions as shown in equation 1 and 2 below. The onset of hardening of insoluble limestone fills up the cracks [1]. 


$$
\begin{aligned}
& \mathrm{CaO}+\mathrm{H}_{2} \mathrm{O} \rightarrow \mathrm{Ca}(\mathrm{OH})_{2} \\
& \quad \ldots \ldots \ldots . . .(1) \\
& \mathrm{Ca}(\mathrm{OH})_{2}+\mathrm{CO}_{2} \rightarrow \mathrm{CaCO}_{3}+\mathrm{H}_{2} \mathrm{O}
\end{aligned}
$$

The calcium oxide reacts with water, generating calcium hydroxide as the result. Reaction of this calcium hydroxide with carbon dioxide provides calcium carbonate as the end product together with egress of water. The water molecules generated in this reaction help in converting the calcium oxide further into calcium hydroxide and the reaction continues until all the available calcium oxide breaks down. With this background, following section explicitly describes the research work already conducted in the field of bacterial concrete.

\section{LITERATURE SUMMARY}

Concrete is one of the most extensively used construction material. It is a strong, readily available and relatively less expensive construction material hence used universally. One disadvantage is because of the mass production of concrete, it causes adverse effects on the nature. The production, mining and transportation of the components of concrete such as cement, sand, and aggregates, lead to increase in greenhouse effect, energy utilization, and environment disfigurement. The statistics estimate that the production of portland cement itself contributes to $7 \%$ of total global $\mathrm{CO} 2$ emissions. This is attributed to the sintering process of clay and limestone at $1500{ }^{\circ}$ Celsius temperature, This process majorly converts calcium carbonate $(\mathrm{CaCO} 3)$ to calcium oxide $(\mathrm{CaO})$ along with release of $\mathrm{CO} 2$ [2]. Hence, concrete doesn't appear to be an acceptable material if observed from environmental point of view. Another drawback is susceptibility of concrete to cracking, a fact which reduces its durability. The effect of life span-associated issues on country's economy can be marked and are evident from the amount of money spent on conservation, retrofitting and reconstruction of concrete structures [3]. Distress and defects with respect to the total life of structures, are generally expected with any kind of building material [4]. Especially, cracks on the uppermost coat of concrete decrease its life span as entered moisture and harmful chemicals cause deterioration and corrosion of the reinforcement within [5]

With extreme weather conditions being common phenomena, concrete structures are exposed to micro level decrepitude. The pores in concrete lead to provision of ways for liquids and gases containing harmful substances to pass through. These substances pose potential threats to the structure's integrity [6]. Even though for many years the necessity of producing more maintainable cement products is acknowledged and executed, the development of sustainable repair methods concrete structures is yet in its preliminary stages. Formation of cracks is generally taken care by observation and renovation by infusing the cracks with epoxy-based, cement- based or other synthetic filler materials [5].

A more defendable restoration method which is based on the application of mineral-producing bacteria is currently being studied in several laboratories [7, 8]. Ureolytic bacteria from family Bacillus were utilized as a medium for biologically producing calcite based minerals in some of these investigations. The procedure of $\mathrm{CaCO} 3$ production by these bacteria is based on the enzymatic chemical reaction of urea with carbon dioxide and ammonia. This method proved to be more favorable for cracks repair in concrete as it increased the strength and reduced the permeability of the material [4]. Bacteria immobilized in light weight aggregate, was tested in concrete. This mixture also exhibited noteworthy improvement in concrete's compressive strength [9]. Chloride test conducted on bacterial concrete specimen exhibited that the adding bacteria decreases weight loss that occurs due to chloride exposure and enhances the compressive strength [10]. As per the research carried out by Jonkers et al, [11], it was observed that bacterial concrete specimens appeared to generate significantly more crackplugging minerals than control specimens.

The most promising type of bacteria for self-healing function is alkali philic (alkali-resistant) spore forming bacteria [12]. A particular group of alkali-resistant spore forming bacteria belonging to the genus Bacillus was chosen for the current purpose. Based on the literature review referred, it was found that various studies has been conducted in regards with comparing bacterial concrete with conventional concrete. Studies have results where the cracks have healed by the addition of bacteria of Bacillus family in concrete. Studies have majorly used methods like encapsulation and bacterial spore addition for concrete testing and seldom used direct bacterial solution addition. Effect of direct addition of bacterial solution in concrete and surface application of solution to test its sealing properties, needs to be accessed and tested.

\section{METHODOLOGY OF THE STUDY}

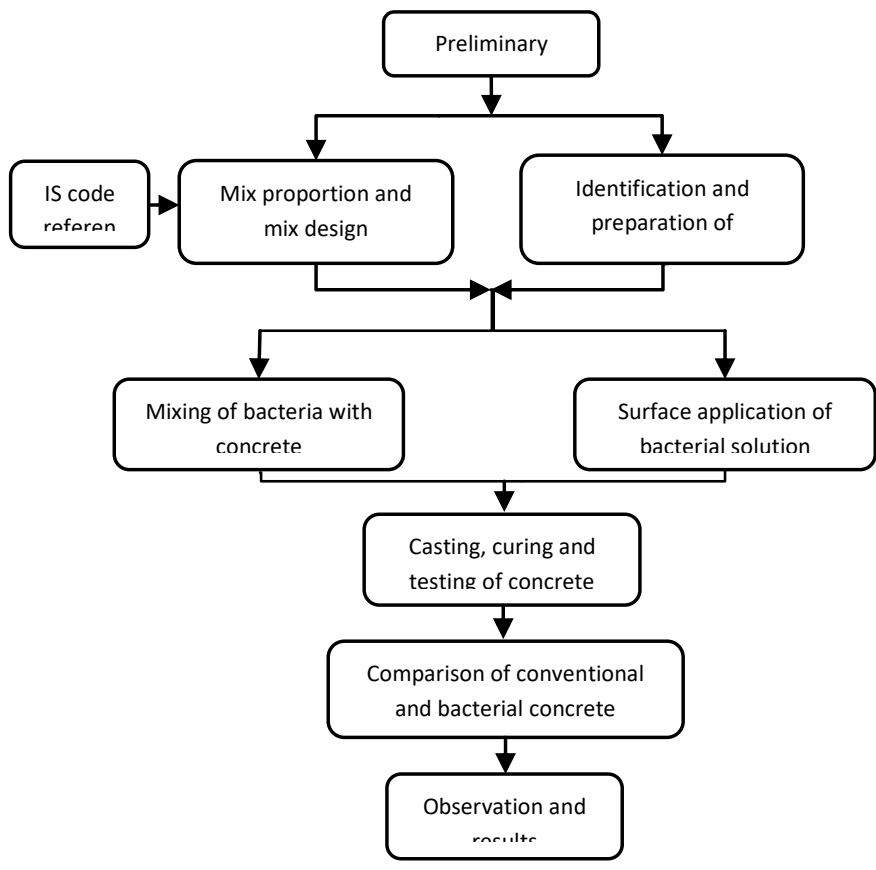

Figure 2: Methodology of the study

Published By: Blue Eyes Intelligence Engineering 
The preliminary work required to be carried out is to select the suitable bacteria, select the process of cultivation, refer to relevant IS code and finalize upon the mix proportion of cement sand and aggregate in concrete along with water and bacterial solution. The study majorly focuses on two aspects which deal with testing the compressive strength and surface sealing capacity of bacterial solution on concrete surface (Fig 2). Following sub-sections describe the methods in detail.

\section{A. Cultivation of bacteria}

The pure culture of bacteria Bacillus Subtilis and Bacillus Sphaericus is conserved on nutrient agar slants that forms irregular desiccated white colonies on them. Inoculation of four different colonies of the bacteria into nutrient broth each of $250 \mathrm{ml}$ in $500 \mathrm{ml}$ conical flask is carried out. It is incubated at the temperature of $37^{\circ} \mathrm{C}$ and $170 \mathrm{rpm}$ in orbital shaker incubator. The medium composition used for bacterial culture's growth consists of $\mathrm{NaCl}$, Peptone, yeast extract. Processes include sterilization, inoculation and incubation. Sterilization is done to achieve sterile environment by killing the microbes. It's done in an autoclave or pressure cooker at a temperature of $121^{\circ} \mathrm{C}$ for 25 to 30 minutes. Inoculation is the streaking of the bacteria on to the media with the help of an open loop. Incubation is done to grow and maintain the bacterial cultures. Fig 3 and Fig 4 showcase the process of bacteria cultivation carried out in biological sciences laboratory.
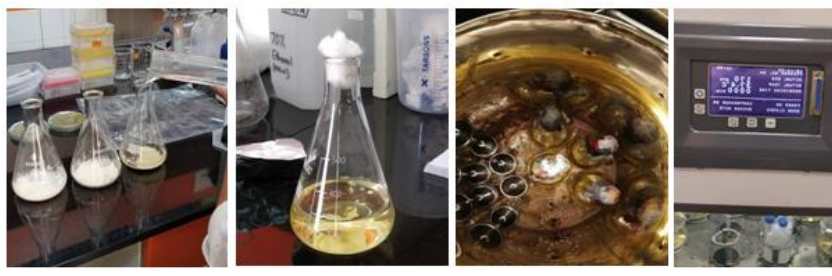

Figure 3: Pictorial representation of bacterial cultivation process

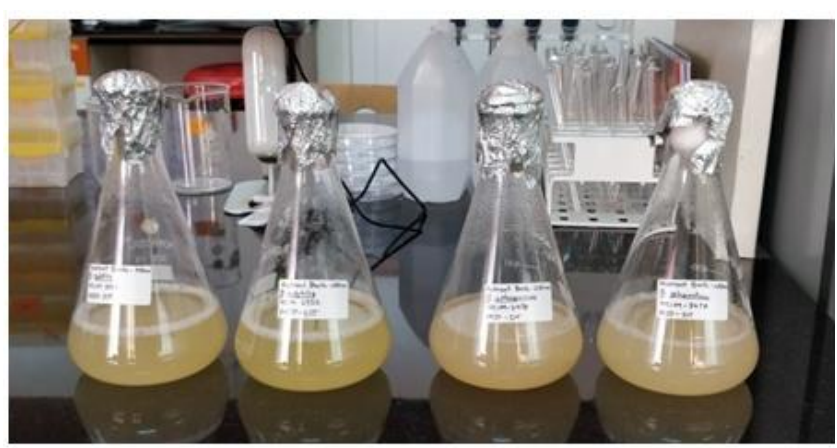

Figure 4: Cultivated bacterial solution

\section{B. Experimentation work}

The work is mainly divided into two parts:

i. Testing compressive strength of bacterial concrete

ii. Testing the possibility of using bacterial solution as a water proofing agent

1. Concrete cube casting for compressive strength test- In order to test the compressive strength of concrete after addition of bacterial solution to it, following process is followed. It includes fixing mix design proportions of cement, sand and aggregate along with water content in the mix. The grade chosen for the study is M20 as results of M15 outnumbered the results of similar tests on M15. Bacterial solution prepared on the basis of process already mentioned, is added in concrete in specific proportions. These include four combinations in varied quantities of solution in concrete during mixing. Following chart (Fig 5) represents the total quantity of blocks casted for the testing. B1 represents Bacillus Subtilis and B2 represents Bacillus Sphaericus. For each combination, 3 blocks are casted for 7 , 14 and 28 days' compressive strength test. Total 81 concrete blocks were casted and tested for the present study.

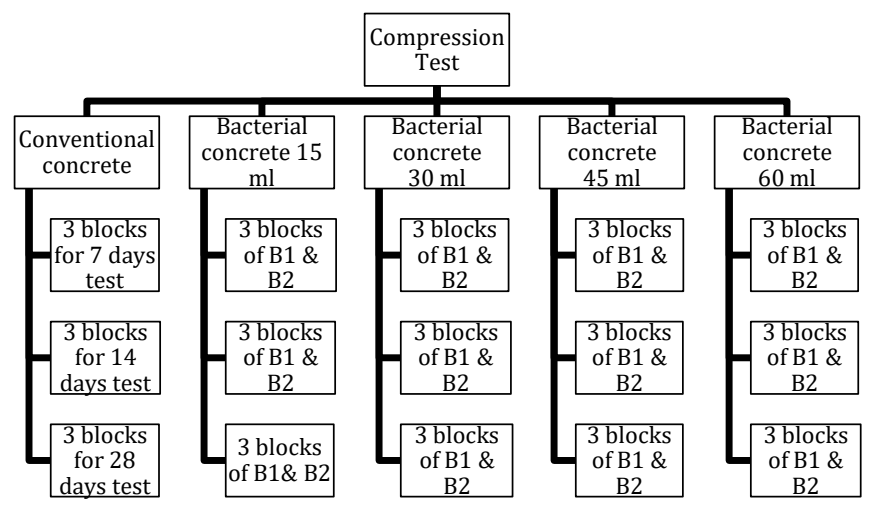

Figure 5: Concrete casting details

2. Design of concrete slabs - A total of eight concrete slabs were casted for carrying out seepage check i.e. the test was conducted to check the permeability and determining the surface applicability of bacterial concrete. The dimensions of each concrete slab were $450 * 450 * 150$ respectively as shown in Fig. 6.
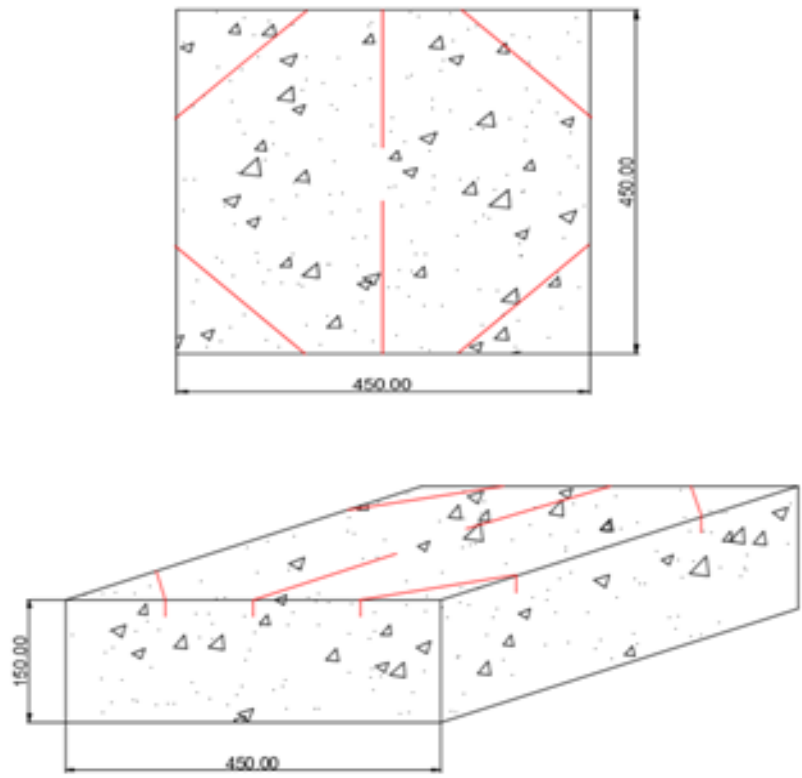

Figure 6: Top view and side view of slab design (all dimensions in $\mathbf{m m}$ )

Published By: Blue Eyes Intelligence Engineering \& Sciences Publication 
Intentional cracks of same dimensions were developed on the surface of each casted slab (Fig 7, 8 and 9). The main purpose of this experiment was to estimate the time taken for certain amount of seepage that takes place through these intentional cracks. Ponding of concrete slabs was done (Fig 10) and the amount of water loss was noted. Once the actual seepage is determined, then bacterial solution was applied on the surface of concrete slab. This was done in order to check the effect of different combination (Bacillus Subtilis or Bacillus Sphaericus) of bacteria in different quantities.

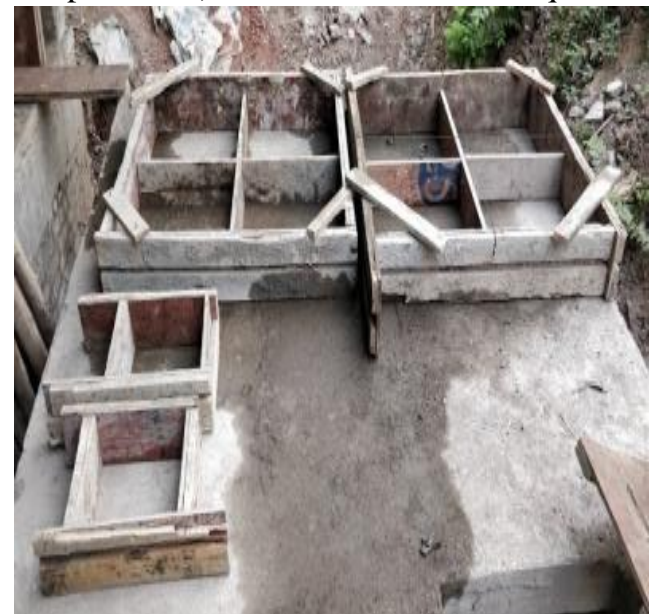

Figure 7: Shuttering provided for casting of slabs

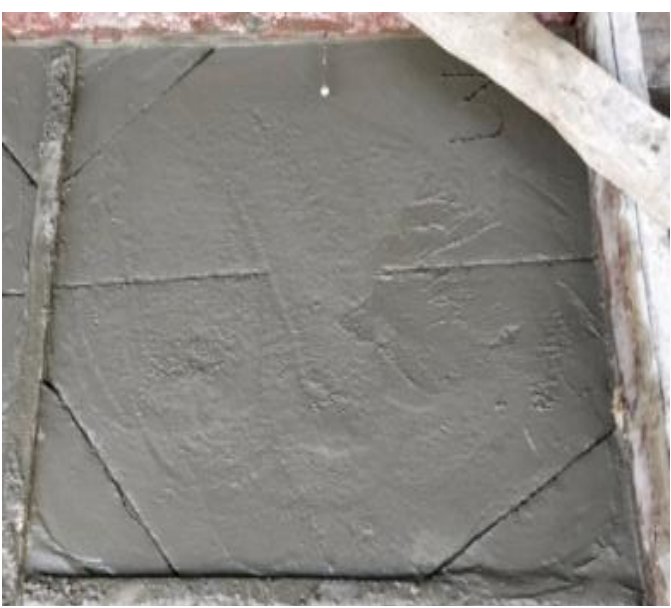

Figure 8: Slab with intentional cracks

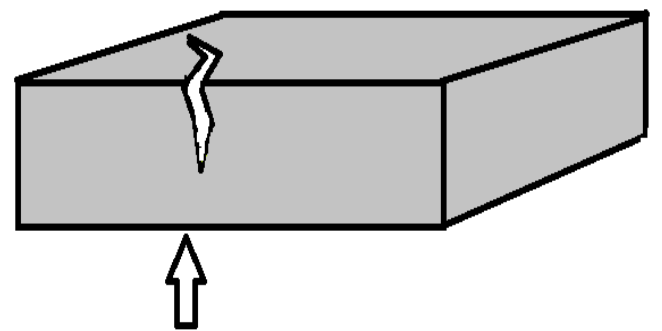

Cracks developed in concrete are inserted with bacteria.

Figure 9: Crack filling process in slabs

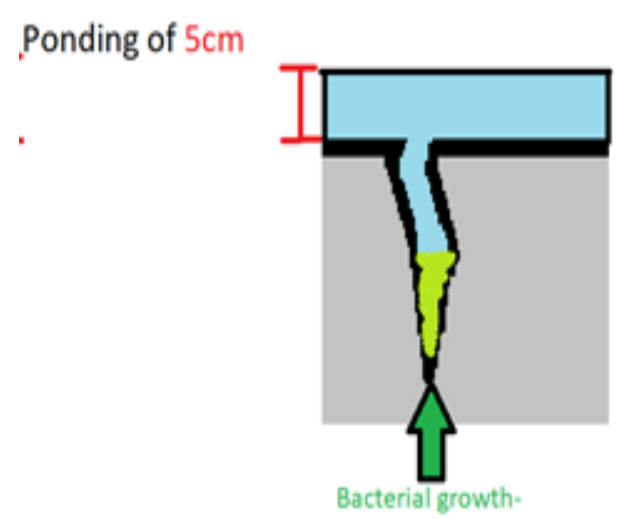

Figure 10: Formation of bacteria in Slabs

\section{OBSERVATIONS AND RESULTS}

This section compiles the outcomes of the tests carried out. The tests were performed for both Bacillus Subtilis and Bacillus Sphaericus solutions in varied proportions.

A. Observations from compression test performed on concrete cubes

Table 1 exhibits the results of compressive strength tests conducted on all the concrete blocks. Universal testing machine has been used to assess the compressive strength.

Table 1: Result of compressive strength test

\begin{tabular}{|c|c|c|c|c|}
\hline $\begin{array}{c}\text { Bacterial } \\
\text { solution } \\
\text { used }\end{array}$ & $\begin{array}{c}\text { Bacterial } \\
\text { concentration }\end{array}$ & $\begin{array}{c}\text { 7 Days } \\
\text { Results }\end{array}$ & $\begin{array}{c}\text { 14 Days } \\
\text { Results }\end{array}$ & $\begin{array}{c}\text { 28 Days } \\
\text { Results }\end{array}$ \\
\hline \multirow{3}{*}{$\begin{array}{c}\text { Bacillus } \\
\text { Subtilis }\end{array}$} & $15 \mathrm{ml}$ & 9.17 & 15.89 & 26.27 \\
\cline { 2 - 5 } & $30 \mathrm{ml}$ & 8.56 & 10.92 & 21.99 \\
\cline { 2 - 5 } & $45 \mathrm{ml}$ & 7.88 & 10.01 & 17.73 \\
\hline \multirow{3}{*}{$\begin{array}{c}\text { Bacillus } \\
\text { Sphaericus }\end{array}$} & $60 \mathrm{ml}$ & 6.49 & 10.15 & 19.04 \\
\cline { 2 - 5 } & $15 \mathrm{ml}$ & 21.92 & 26.79 & 28.57 \\
\cline { 2 - 5 } & $30 \mathrm{ml}$ & 27.48 & 29.61 & 48.43 \\
\cline { 2 - 5 } & $45 \mathrm{ml}$ & 27.74 & 32.09 & 36.73 \\
\hline
\end{tabular}

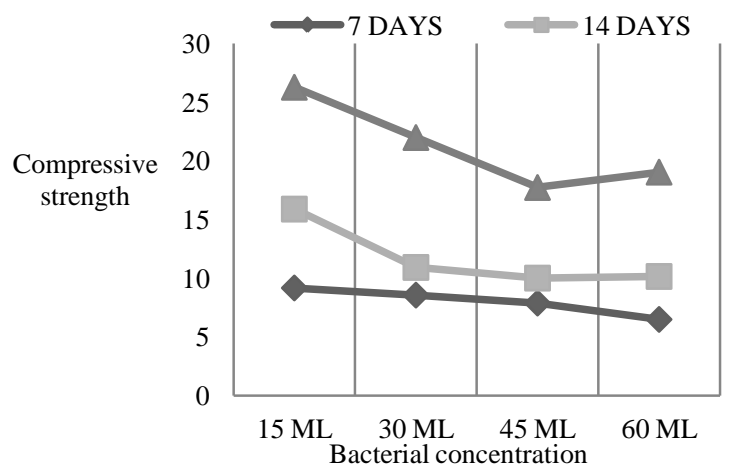

Figure 11: Compressive strength test results for Bacillus Subtilis solution 
It is evident from above graph (Fig. 11) that combination with $15 \mathrm{ml}$ bacterial solution in concrete gives better result for compressive strength than any other combination. For both 7 days and 28 days compressive strength test, the maximum value was obtained when $15 \mathrm{ml}$ of Bacillus Subtilis solution was added to M20 grade of concrete. Similarly, a comparative graph of compressive strengths is generated for Bacillus Sphaericus (Fig 12). It is observed that for 7 days and 28 days compressive strength test, the maximum value was obtained when $30 \mathrm{ml}$ of Bacillus Sphaericus solution was added to M20 grade of concrete.

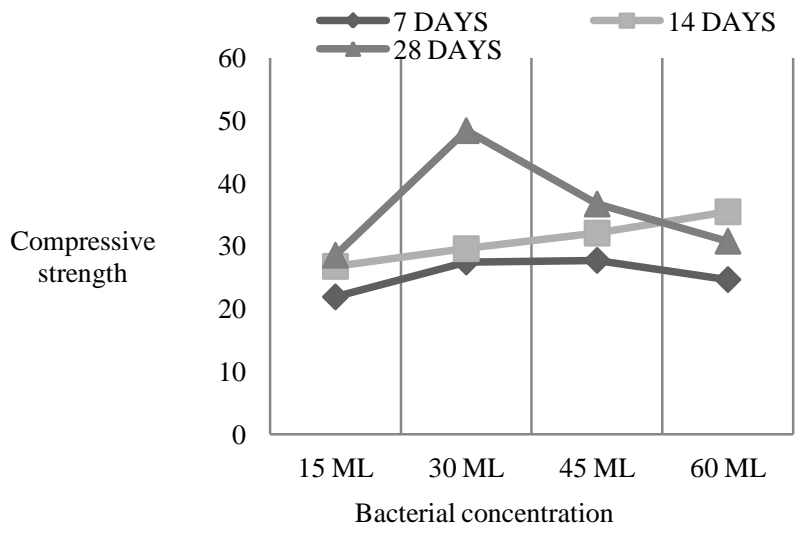

Figure 12: Compressive strength test results for Bacillus Sphaericus solution

\section{B. Result for seepage test performed on concrete slabs}

Table 2: Seepage test results

\begin{tabular}{|c|c|c|c|}
\hline Sr.nd & $\begin{array}{c}\text { Slab Serial } \\
\text { No. }\end{array}$ & Type of top coat & $\begin{array}{c}\text { Average total time } \\
\text { for Seepage }\end{array}$ \\
\hline 1 & Slab 1 & Conventional & $1 \mathrm{hr} 36 \mathrm{mins}$ \\
\hline 2 & Slab 2 & Bacteria (B1) & $1 \mathrm{hr} 40 \mathrm{mins}$ \\
\hline 3 & Slab 3 & Bacteria (B1) & $1 \mathrm{hr} 50 \mathrm{mins}$ \\
\hline 4 & Slab 4 & Bacteria (B1) & $1 \mathrm{hr} 48 \mathrm{mins}$ \\
\hline 5 & Slab 5 & Conventional & $1 \mathrm{hr} 50 \mathrm{mins}$ \\
\hline 6 & Slab 6 & Bacteria (B2) & $5 \mathrm{hr} 50 \mathrm{~min}$ \\
\hline 7 & Slab 7 & Bacteria (B2) & $5 \mathrm{hr} 45 \mathrm{mins}$ \\
\hline 8 & Slab 8 & Bacteria (B2) & $5 \mathrm{hr} 53 \mathrm{mins}$ \\
\hline
\end{tabular}

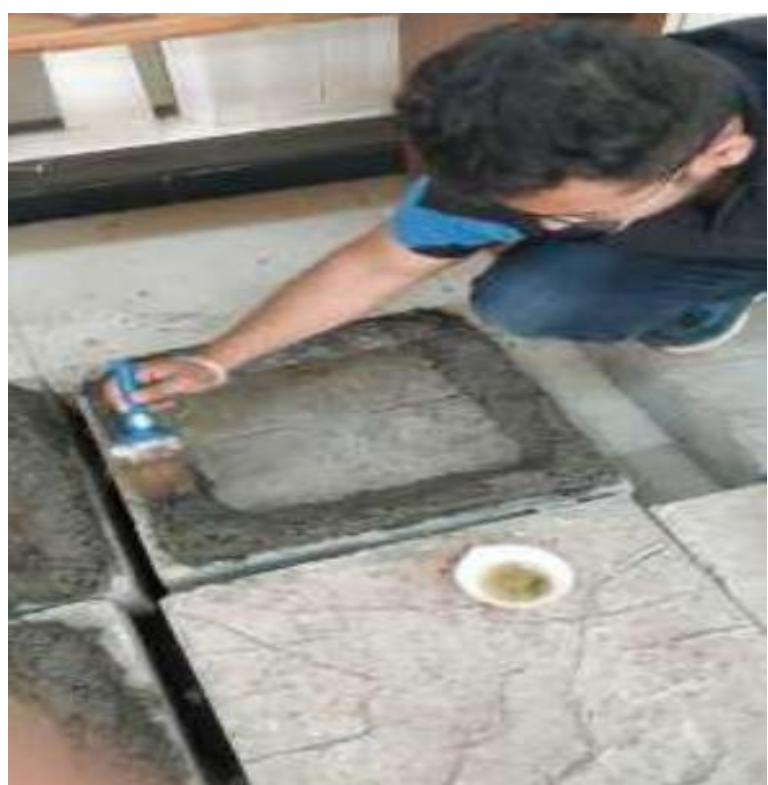

Figure 13: Top coat of bacterial solution

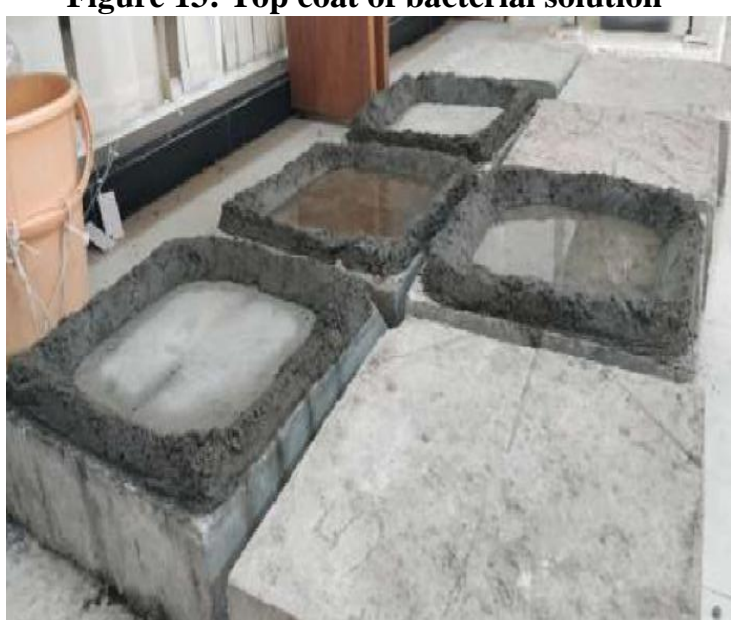

Figure 14: Seepage Test on concrete slabs

Based on the test conducted, Table 2 compiles the results which depict that layer of Bacillus Sphaericus on the concrete slab surface gives better results for seepage protection than Bacillus Subtilis.

\section{CONCLUSION}

For strength assessments, cubes were tested for different bacterial concentrations. It was observed that the compressive strength of concrete showed significant increase with the addition of bacteria. $30 \mathrm{ml}$ of Bacillus Sphaericus in concrete mix M20 shows the maximum improvement in compressive strength as compared with the conventional concrete's strength. Upon application of the selected bacteria, it was witnessed that it can also be used as waterproofing material. Bacillus Sphaericus showed better results as a waterproofing material and seepage control as it works better than Bacillus Subtilis.

Bacterial concrete is fairly new concept and is implementable on site. It is easy to prepare and requires basic knowledge of bacteria and cultures. It is a very innovative idea to make use of these natural phenomena of bacteria to improve concrete's performance. The solution is not only reliable but also increases durability of the structure making it maintenance free. Comparatively, this technique is cheaper than the methods that are resorted to in case of crack formation and deterioration of the structure. It thus requires due attention in order to make a more sustainable infrastructure to move towards a more eco friendly construction practices.

\section{REFERENCES}

1. https://theconstructor.org/concrete/bacterial-concreteselfhealing-concrete/13751/- Accessed on 5th January 2019.

2. Worrell, E., Price, L., Martin, N., Hendriks, C., Ozawa Meida, L., (2001). Carbon dioxide emissions from the global cement industry. Annu. Rev. Energy Environ. 26, 303-329.

3. FHWA-RD-01-156, September 2001. Corrosion cost and preventive strategies in the United States, Report by CC

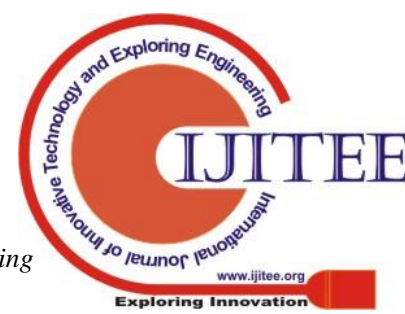


Technologies Laboratories, Inc. to Federal Highway Administration. (FHWA), Office of Infrastructure Research and Development.

4. De Muynck, W., De Belie, N. and Verstraete, W. (2010) "Microbial carbonate precipitation in construction materials." Ecological Engineering, 36(2) pp. 118-136.

5. Neville, A.M., (1996). Properties of Concrete. Pearson Higher Education, 4th edition. Prentice Hall, New Jersey.

6. Van Tittelboom, K., De Belie, N., De Muynck, W. and Verstraete, W. (2010) "Use of bacteria to repair cracks in concrete." Cement and Concrete Research, 40(1), Elsevier Ltd, pp. 157-166.

7. Chaturvedi, S., Chandra, R., Rai, V., (2006). Isolation and characterization of Phragmitesaustralis (L.) rhizosphere bacteria from contaminated site for bioremediation of colored distillery effluent. Ecol. Eng. 27, 202-207.

8. Jugnia, L.B., Cabral, A.R., Greer, C.W., (2008). Biothic methane oxidation within an instrumented experimental landfill cover. Ecol. Eng. 33, 102-109.

9. Wasim Khaliq, Muhammad Basit Ehsan (2015), Crack healing in concrete using various bio influenced selfhealing techniques. Construction and Building Materials, p. 349-357.

10. Meera .C.M., Lakshmi.L , Eldhose Cheriyan, (2016). Durability and Self- Healing Behaviour of Bacterial Impregnated Concrete.International Journal of Innovative Research in Science, Engineering and Technology (An ISO 3297: 2007 Certified Organization) Vol. 5, Issue 8 , August 2016.

11. H.M. Jonkers, A. Thijssen, G. Muyzer, O. Copuroglu, E. Schlangen, (2010), Application of bacteria as selfhealing agent for the development of sustainable concrete Ecol. Eng. 36 (2) 230-235.

12. Kudatakar P., Mahalaxmi M.M, Madan V.R., Joshi T., (2014). An Experimental Investigation on Strength Aspects of Bacterial Concrete, IRJET, Vol 6, Issue 4

\section{PROFILE}

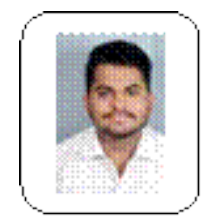

Shubham Ajay Puranik, B.Tech Civil Engineering graduate (2015-19) from Symbiosis Institute of Technology (S.I.T), Pune. Active participant in research study on Bacterial concrete (Funded Project), Smart city recommendations and proposals. Recipient of Best paper award at INFRACON, International Conference held at

SCMHRD, Pune.

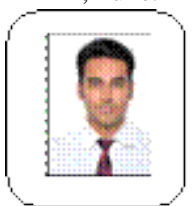

Siddharth Jain, B.Tech Civil Engineering graduate (2014-18) from Symbiosis Institute of Technology (S.I.T), Pune. Gold medal awardee from the President of India - Shri Ram Nath Kovind Ji. Currently pursuing M.Tech in Construction management, MIT WPU, Pune.

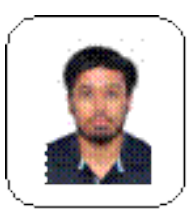

G. Sritam, B.Tech Civil Engineering graduate (2014-18) from Symbiosis Institute of Technology (S.I.T), Pune.. Currently pursuing MBA in Finance, ITM, Mumbai.

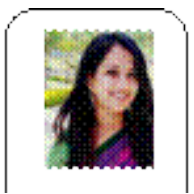

Dr. Sayali Sandbhor is an Assistant Professor at Department of Civil Engineering, Symbiosis Institute of Technology, Symbiosis International (Deemed University) with an experience of more than 7years in teaching. She has obtained her PhD. From Symbiosis International (Deemed University) in

Property valuation and has area of expertise in legal aspects in construction, construction management, use of artificial intelligence in civil engineering, quantity estimation and valuation, concrete properties, systems approach in civil engineering etc. 